\title{
奄美群島産ヒメ八ブの食性に関する研究
}

\author{
三 島 章 義 \\ 鹿児島大学医学部附属熱帯医学研究施設 \\ （施設長：佐藤八郎教授） \\ 現所属 : 群馬大学医学部微生物学教室 \\ （主任：三橋 進教授）
}

Résumé : Sîudies on the Feeding Habițs of Trimeresurus okinavensis on the Amami Island. Shogi Mishima (The Research Institute of Tropical Medicine and Hygiene, Faculty of Medicine, Kagoshima University. Chief: Dr. Hachiro Sato. Present Address : Department of Microbiology, School of Medicine, Gunma University. Chief : Dr. Susumu Mitsuhashi)

For a period of 5 years beginning with 1959, the feeding habits in the wild of the "Hime-Habu" (Trimeresnrus okinaveinsis) on the Amami Islands were studied, with the following results:

1) The animals fed on were vertebrates of 7 families, 9 genera, 12 species. They were divided as follows: Mammals — 2 families, 2 genera, 2 species; Birds — 1 family, 1 genus, 1 species; Reptiles - 1 family, 3 genera, 3 species; Amphibians _ 3 families, 3 genera, 6 species.

2) Of the animals in 1), 10 species were recorded for the first time.

3) A total of 31 animals were recorded of which $61.3 \%$ were amphibians, $19.4 \%$ reptiles, $16.1 \%$ mammals, and $3.2 \%$ birds.

Of the total, the "Ryukyu Aka-Gaeru" (Rana okinavana) and the "Hanasaki-Gaeru" (Rana narina) accounted for $41.2 \%$. These frogs were presumed to be the principal food of the "Hime-Habu".

4) Judging from the animals eaten, the "Hime-Habu" was presumed to inhabit narrow forested valleys; observations in the field confirmed this.

5) Judging from the feeding habits and the habitat, the "Hime-Habu" and the "Habu" (Trimeresurus $f$. flavoviridis) were presumed to be completely allopatric.

6) A maximum length of $783 \mathrm{~mm}$ for the "Hime-Habu" from the Amami Islands was recorded.

7) An instance of the "Hime-Habu" eating a snake longer than itself was recorded.

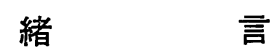

ヒメハブ Trimeresursu okinavensis Boulenger, 1892 は，奄美群島と沖繩群島の固有種で，毒 蛇である。その形態が本士産のマムシ Agkistrodon halys（Pallas，1776）によく似ており，奄 美大島では“マムシ”あるいは“クゥージラク”と呼ばれている。毒性もマムシに似ていて，局所 におけるいわゆる出血毒を主としている。しかしながら分布域を殆んど同じくする八ブ Trimeresurus flavoviridis flavoviridis (Hallowell, 1860) が，毒性・攻撃性・棲息密度ならびに被害発 生率等の点であまりにも有名であるため, その蔭にかくれて行政的にも，また現地の住民にもあま り問題にはされていない。

しかしその咬症は疼痛と腫脹が甚だしくて障害をのこす場合もあり，八ブ咬傷と同様に早急に適 
切な処置が必要である。また同地方における毒蛇咬傷で, 加害蛇が見つからない場合など，ヒメ八 ブ咬傷と八ブ咬傷が間違って報告されることもあり，医学的にも行政的にも無視出来ない問題であ る。従ってハブと共にヒメ八ブの生態学的研究も早急に解決されなければならない問題である。

筆者はヒメハブの生態研究の一環として，その行動や棲息場所に関係の深い食性を明らかにする ため，奄美群島産ヒメ八ブの自然界における捕食物を調查した。

ヒメハブの食物について，高良（1962）はネズミ類などの 4 種を，また木場（1960，1961， 1962，1963）も 4 科・4 属・4 種を報告しているが, 三島（1961）はさらにアカガエル類, ネズミ 類及び小鳥類を捕食していることを記述し，また予報（1965）として7科・9属・12種を報告した。 本報ではその調査の詳細な記載を報告する。

\section{調査の方 法}

奄美大島のハブ捕獲業者は，ハブと共にヒメ八ブも捕獲しており，年間を通じて多数のヒメハブ が集められている。

筆者は1959年 9 月から1964年 8 月までの 5 年間にわたり，これらのヒメ八ブを解剖して得られた 胃内容物ならびに吐出物を検査して, 自然界におけるヒメ八ブの食物の種類とその捕食率を調查し た。

\section{調 査 成 績}

5 年間に調査した奄美群島産ヒメ八ブの自然界に抢ける捕食物の 31 例について，その種類と数の 総括を Table 1. に示した。次に捕食物を分類し，各種類についてそれを捕食していたヒメハブの 採集年月日，採集地抢よびヒメ八ブの全長を記載し，その概要を記述する。

\section{A. 哺乳類 Mammalia}

1. トガリネズミ科 Soricidae

1）ワタセジネズミ Crocidura horsfieldi watasei Kuroda, 1924, (Fig, 1-A)

1961年 5 月 8 日, 大和村字不明, $485 \mathrm{~mm}$

1963年 4 月 3 日，笠利町宇宿, $512 \mathrm{~mm}$

本亜種は奄美大島と徳之島・伊江島からのみ知られ, 頭胴長 $58 \mathrm{~mm}$, 尾長 $45 \mathrm{~mm}$ 前後の小型で 夜行性のジネズミで，一般にはあまり知られていないが，奄美大島では山地や原野にかなり棲息し ているようである。ヒメ八ブの捕食物としては初めての記録である。

2. ネズミ科 Muridae

2) クマネズミ Rattus rattus (Linnaeus, 1758), (Fig. 1-B)

1961年 3 月 9 日, 笠利町笠利, $729 \mathrm{~mm}$

1961年 5 月 6 日, 笠利町手花部, $636 \mathrm{~mm}$

1962年 9 月 16 日, 住用村見里, $682 \mathrm{~mm}$

本種の捕食例は，いずれも亜成体であった。

B. 鳥類 Aves

3. キンパラ科 Ploceidae

3）スズメ Passer montanus saturatus Stejneger, 1885, (Fig. 2) 
1963年 7 月 13 日, 名瀬市崎原町。564 $\mathrm{mm}$

本亜種は奄美大島でも普通に見られる留鳥である。ヒメハブの捕食物としては初めての記録であ る。

\section{C. 爬虫類 Reptilia}

4. ヘビ科 Colubridae

4）リュウキュウアオヘビ Opheodrys semicarinatus (Hallowell, 1860), (Fig. 3-A)

1961年 6 月 19 日, 大和村名音, $536 \mathrm{~mm},(573 \mathrm{~mm})$

1962年 4 月 3 日, 大和村大和浜, $532 \mathrm{~mm},(565 \mathrm{~mm}$ )

1962年 6 月11日, 大和村大和浜, $655 \mathrm{~mm},(466 \mathrm{~mm})$

（）内は捕食されていた蛇の全長を示す（以下同様に略記する）。本種は琉球列島の固有種で, ガラスヒバアとともに奄美群島では最も普通に見られる中型の蛇である。一般に森林や原野の水辺 に多く棲息し，昼行性であるが，夜間も活動している。

本種の捕食例では, ヒメハブが自長よりも体長の大なる本種を捕食していた 2 例が知られ, 特異 な捕食例として興味深い。ヒメ八ブによる捕食例としては初めての記録である。

5) アカマタ Dinodon semicarinatus (Cope, 1860), (Fig. 3-B)

1963年 6 月15日, 住用村西仲間。632 $\mathrm{mm}$, $(510 \mathrm{~mm}$ )

本種は奄美・沖繩両群島の固有種で, 奄美群島では八ブと並んで大型の蛇である。一般に原野の 水辺や水田耕作地帯に棲息し，夜行性である。ヒメハブによる捕食例としては初めての記録であ る。

6）ガラスヒバア Natrix pryeri pryeri (Boulenger, 1887), (Fig. 3-C)

1962年 4 月 9 日, 住用村山間, $413 \mathrm{~mm},(333 \mathrm{~mm})$

1964年 5 月 13 日，笠利町用安， $562 \mathrm{~mm},(635 \mathrm{~mm})$

本亜種は琉球列島の固有種で, 奄美群島ではリュウキュウアオへビとともに最も普通の蛇である。 一般に山地や平地の水辺, 田畑等の湿地帯に棲息し，主にカエル類を捕食している。昼行性である が夜間も活動している。ヒメ八ブが自長よりも全長の長い本種を捕食していた 1 例は, リュウキュ ウアオヘビの例とともに興味深い。

\section{D. 両棲類 Amphibia}

5. アマガエル科 Hylidae

7) ハローウェルアマガェル Hyla hallowellii Thompson, 1912, (Fig. 4-A)

1963年11月11日，名瀬市朝戸町， $385 \mathrm{~mm}$

本種は奄美群島の固有種で, 人家や耕作地帯周辺に多く, 植物葉上によく見かける。一般に植物 の葉上生活を営むといわれている。

6. アカガエル科 Ranidae

8）リュウキュウアカガェル Rana okinavana Boettger, 1895, (Fig. 4-B)

1961年 7 月 12 日, 大和村福元, $612 \mathrm{~mm}$

1961年 7 月 12 日, 大和村福元, $413 \mathrm{~mm}$

1962年 6 月 3 日, 住用村川内, $383 \mathrm{~mm}$

1962年11月 8 日, 大和村大和浜, $563 \mathrm{~mm}$

1963年 4 月 15 日, 大和村名音, $398 \mathrm{~mm}$

本種は琉球列島の固有種である。森林地帯の渓流を中心に多数棲息し，奄美六島ではいわゆる真 冬の季節にも見られ，一般に夜間の活動が曊著である。ヒメ八ブによる捕食例としては初めての記 録である。 
9） ヌマガエル Rana limnocharis limnocharis Wiegmann, 1835, (Fig, 4-C)

1963年 4 月 9 日，笠利町赤木名, $538 \mathrm{~mm}$

1964年 4 月 3 日, 名瀬市生産町, $395 \mathrm{~mm}$

本亜種の分布域は広いが，琉球列島では極めて普通の蛙であり，特に平地の水田およびその周辺 には多い。ヒメハブによる捕食例としては初めての記録である。

19）ハナサキガエル Rana narina Stejneger, 1901, (Fig. 4-D)

1961年12月 9 日, 大和村福元, $663 \mathrm{~mm}$

1961年12月19日, 大和村名音, $738 \mathrm{~mm}$

1961年12月 23 日, 大和村大和浜, $783 \mathrm{~mm}$

1962年 9 月 11 日, 大和村大和浜, $580 \mathrm{~mm}$

1963年 3 月 8 日, 住用村城, $616 \mathrm{~mm}$

1963年 4 月 5 日, 大和村大和浜, $596 \mathrm{~mm}$

1964年 2 月 12 日, 大和村大棚, $700 \mathrm{~mm}$

本種は琉球列島と台湾に分布し，奄美群島ではオットンガエルについで大型の種類である。本種 もリュウキュウアカガェルとともに森林地帯の渓流に多く棲息する。

7. アオガエル科 Rhacophoridae

11）アマミアオガエル Rhacophorus viridis amamiensis Inger, 1947, (Fig. 4-E)

1963年 4 月 13 日，大和村大棚， $498 \mathrm{~mm}$

本亜種は奄美大島と徳之島の固有種で, 山地にも平地にも水辺の周辺に棲息する。主として植物 の葉上生活を営む。ヒメハブによる捕食例としては初めての記録である。

12）二ホンカジカガェル Rhacophorus japonicus (Hallowell, 1860), (Fig. 4-F)

1961年 5 月 3 日, 住用村西仲間, $386 \mathrm{~mm}$

1962年 3 月29日, 採集地不明, $413 \mathrm{~mm}$

1963年10月 13 日，笠利町字宿, $502 \mathrm{~mm}$

本種は琉球列島と台湾に分布し，山地の森林户や渓谷にも，また平地の水田周辺にも棲息し，そ の生活圈は広範にわたっている。ヒメハブによる捕食例としては初めての記録である。

\section{考察}

ヒメハブの食物については, 高良（1962）がジャコウネズミSuncus caeruleus, クマネズミ属の 1 種 Rattus sp., オキナワハツカネズミ Mus caroli, ウズラ Coturnix coturnix の 4 種を報告し， 木場 (1960, 1961，1962，1963）はオリイジネズミCrocidura orii, リュウキュウウグイスCettia diphone riukiuensis, ガラスヒバア Amphiesma pryeri, 八ナサキガェル Rana narina, の 4 科・ 4 属・4種を報告している。

筆者の調查した Table I.によれば, 得られた 31 例の捕食物中, $61.3 \%$ 両棲類が占めて抢り， これについで爬虫類の $19.4 \%$; 哺乳類の $16.1 \%$; 鳥類の $3.2 \%$ の順となっている。冷血動物の両棲 類と爬虫類を合わせると $81.1 \%$ 高率となり，これは温血動物を主要食物とするハブの成蛇とは極 內て対照的な食性であり，八ブの幼蛇に類似の傾向を示している。しかしハブの幼蛇はトカゲ類を 主体とする爬虫類を好んで捕食しているのに対し，ヒメ八ブでは両棲類が $61.3 \%$ 首位を占め，そ の $73.7 \%$ はュウキュウアカガエルと八ナサキガエルを主体とするアカガエル科のカエル類である ことが注目される。これは捕食例の全体からみても41.2\%の高率であり, アカガエル類がヒメハブ 
Table 1. The natural food of Trimercsirus okinavensis on the Amami Islands

\begin{tabular}{|c|c|c|c|}
\hline Items of prey & $\begin{array}{l}\text { Nos. } \\
\text { of } \\
\text { prey }\end{array}$ & $\begin{array}{l}\% \text { to } \\
\text { total } \\
\text { preys }\end{array}$ & $\begin{array}{l}\text { Nos. of } \\
\text { snake } \\
\text { with prey }\end{array}$ \\
\hline 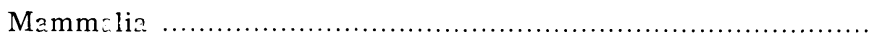 & $(5$ & 16.1 & $5)$ \\
\hline \multicolumn{4}{|l|}{ Soricidae } \\
\hline * Crocidura horsfield'i watasei ワタセジネズミ .................. & 2 & & 2 \\
\hline \multicolumn{4}{|l|}{ Muridze } \\
\hline 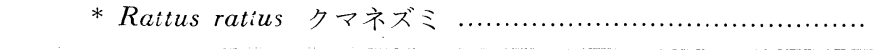 & 3 & & 3 \\
\hline Aves & ( 1 & 3.2 & $1)$ \\
\hline \multicolumn{4}{|l|}{ Ploceidae } \\
\hline 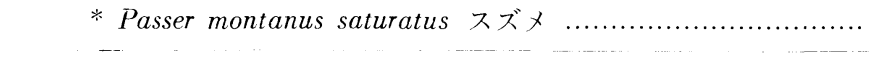 & 1 & & 1 \\
\hline 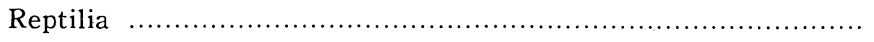 & $(6$ & 19.4 & $6)$ \\
\hline \multicolumn{4}{|l|}{ Colubridae } \\
\hline * Opheodrys semicarinatus リュウキュウアオへビ $\ldots \ldots \ldots \ldots \ldots$ & 3 & & 3 \\
\hline 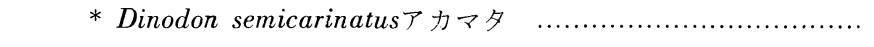 & 1 & & 1 \\
\hline 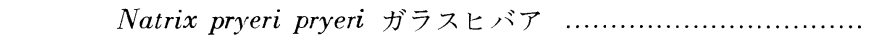 & 2 & & 2 \\
\hline 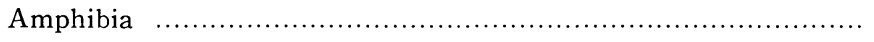 & $(19$ & 61.3 & $19)$ \\
\hline \multicolumn{4}{|l|}{ Hylidae } \\
\hline 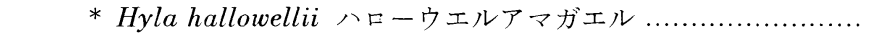 & 1 & & 1 \\
\hline \multicolumn{4}{|l|}{ Ranidae } \\
\hline * Rana okinavana リュウキュウアカガエル ..................... & 5 & & 5 \\
\hline 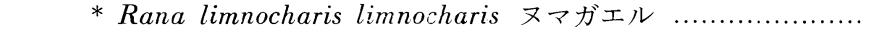 & 2 & $(41.2)$ & 2 \\
\hline 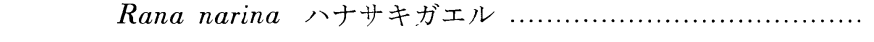 & 7 & & 7 \\
\hline \multicolumn{4}{|l|}{ Rhacophoridae } \\
\hline * Rhacophorus viridis amamiensis アマミアオガエル .............. & 1 & & 1 \\
\hline 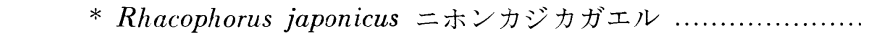 & 3 & & 3 \\
\hline ................ & $(31$ & 100.0 & $32)$ \\
\hline
\end{tabular}

の主要食物となっていることが推察される。この結果, 十分とはいえないまでも, ヒメ八ブの自然 界に拉ける食物の傾向を知ることができた。

三島（1961，1965）は既に野外の観察の結果，ヒメハブが一般に山地森林地帯に棲息し，殊にリ ュウキュウアカガエルの多数棲息する山間峡谷には多く見かけることを記述したが，この傾向は捕 食率からみた食性とも合致している。奄美大島のハブ捕獲人は，ヒメ八ブの採集を目的とする場合 は，リュウキュウアカガエルの鳴き声を追って山間陕谷を踏查し，冬期でも採集に好成績をあげて いる。彼等はアカガエル類の群棲地には, ヒメハブが多数出没していることを経験的に知っている ようである。

以上のことから，八ブがクマネズミ類を主とする温血動物を主要食物として，一般に耕作地帯を 中心に棲息するのに対し，アカガエル類を主要食物とするヒメ八ブは，森林峡谷を中心に棲息して おり，両者にはその食性の相違から，明らかに“生態学的棲み分け” の現象があるものと考えられ る。

ヒメハブの大きさについて，高良（1962）は沖繩島産のヒメ八ブで $889 \mathrm{~mm}$ の個体を記載してい る。奄美群島産ヒメハブについては，木場（1962）は7 $75 \mathrm{~mm}$ の個体を記載し，三島（1961）は 
$725 \mathrm{~mm}$ の個体を記載しており，これが今までの最大の記録であった。

本報における $738 \mathrm{~mm}$ と $783 \mathrm{~mm}$ の 2 例は, 奄美群島産ヒメ八ブでは最大の記録である。奄美群 島産ヒメハブでは，全長が $700 \mathrm{~mm}$ を越える個体はあまり多くない。

八ローウエルアマガエルやアマミアオガエルなど，一般に植物の葉上生活を営むといわれている 種類が，登樹性のない純地上生活者でしかも運動の遅鈍なヒメ八ブに捕食されている事実は，両種 が地上での生活も営なむことを示しているものと推察する。

ヒメハブの大きさと食物の種類との関係については，更に調査を続けて検討することが必要であ ると考える。

\section{総括}

1959年から 5 年間にわたって, 奄美群島におけるヒメ八ブの自然界における捕食物の種類を調查 し, 次の結果を得た。

1）食餌動物の種類は, 脊椎動物の 7 科・9 属・12種が知られた。これを綱別にみると, 哺乳類 の 2 科・ 2 属 $\cdot 2$ 種; 鳥類の 1 科・ 1 属・ 1 種; 爬虫類の 1 科 $\cdot 3$ 属・ 3 種：両棲類の 3 科・ 3 属・ 6 種となっている。

2）ヒメハブの食餌動物として，新しく 10 種を記載した。

3）調查した捕食例数は31例で，その綱別の捕食率は，両棲類の $61.3 \%$ 首位を占め，これにつ いで爬虫類の $19.4 \%$; 哺乳類の $16.1 \%$; 鳥類の $3.2 \%$ の順となっている。

これらのうちで, リュウキュウアカガエルと八ナサキガエルを主体とするアカガエル科のカエル 類が全体の $41.2 \%$ 占めており，これがヒメハブの主要食物となっていることを指摘した。

4）これらの食餌動物の種類及びその生態から，ヒメ八ブは森林狭谷性のものであると考えられ るが，これはヒメ八ブの野外観察の結果とも一致している。

5）以上の食性及び棲息場所の相違から，ヒメハブと八ブの生態は極めて対照的であり，両者に は“生態学的棲み分け”の現象があるものと考える。

6）奄美群島産ヒメハブとしては最大長の，全長 $783 \mathrm{~mm}$ の個体を記載した。

7）ヒメハブが自長よりも長いへビを捕食している特異な例を報告した。

謝 辞

本研究を進めるにあたり，鹿児島県名瀬保健所八ブ研究室の小野継男技師・松下仁六氏に注終始 格別の協力を得ており，ここに心から感謝の意を表する次第である。

また八ブ捕獲業の中本英一氏・原宮哉氏・南武一郎氏・平栄光氏ならびに各地の八ブ捕獲人の方 々には, 度々の野外調查及び採集蛇の剖検, 吐出標本の提供その他, 本調査にあたって多大の協力 を得ており，ここに厚く感謝申し上げる。

更に食物標本の種名同定に関しては，今泉吉典博士・加納六郎博士・関勝博士・柴田保彦氏など の教示と協力を戴いた。梁く謝意を表する次第である。

本報をまとめるにあたり，懇篤なる指導助言を賜わった加納六郎教授・田中寬助教授・また種々 御高配を賜わった佐藤八郎教授・三橋進教授に感謝の意を表したい。

本報の概要の一部は，第 2 回日本爬虫類学会総会（1963）において報告した。 
The natural food of Trimeresurus okinavensis on the Amami Islands

\section{S. Mishima}
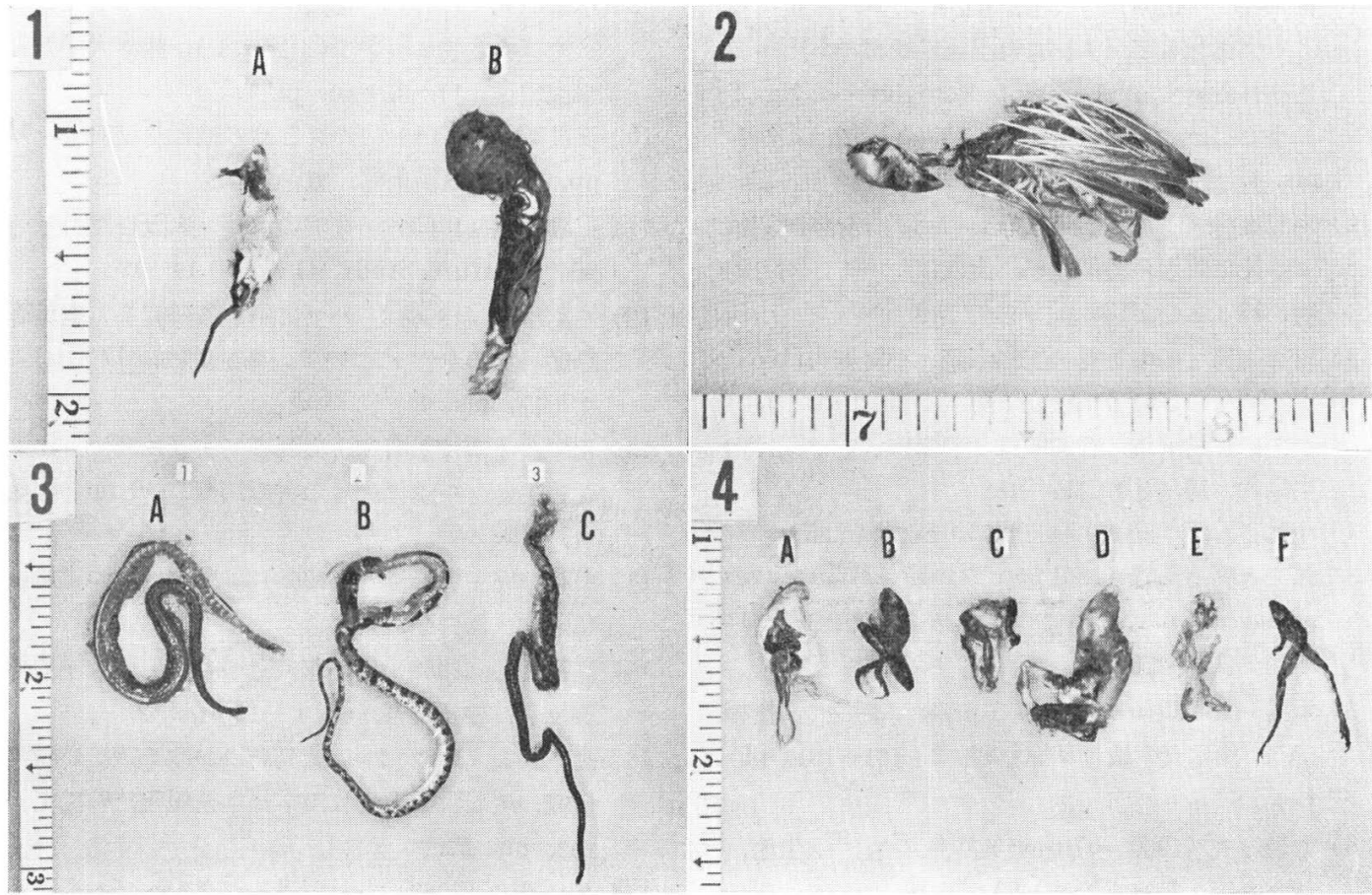

\section{Explanation of plate}

Fig. 1 - A Crocidura horsfieldi watasei

- B Rattus rattus (subadult)

Fig. 2 - Passer montanus saturatus

Fig. 3 - A Opheodrys semicarinatus

- B Dinodon semicarinalus (subadlt)

- C Natrix pryeri pryeri

Fig. 4 - A Hyla hallowellii

- B Rana okinavana

- C Rana limnocharis limnocharis

- D Rana narina

- E Rhacophorus viridis amamiensis

- F Rhacophorus japonicus 


\section{文献}

1）青木謙二 (1963)：ハブ毒・サキシマハブ毒・ヒ メハブ毒执よびマムシ毒等出血性蛇毒の局所病変 とそれに対する $\alpha$-Thiola-ctoylglycin $\mathrm{Na} の$ 効果について。北関東医学, 13 (4) : 231-242, pls. 4.

2）阿部康男・三島章義（1961）： 八ブの身体計測值 より見た雌雄の特徴並びに食性について。衛生動 物, 12 (2): $135 \mathrm{p}$

3）阿部康男 - 田中 寛 ·三島章義・小野継男(1965) : ハブならびにハブ峧症に関する研究 $(\mathrm{Tr}$.- - 3)； 八ブの行動解析, 特に照度との関係について. 衛 生動物, 16（3）: 177-183.

4）小此木丘・本間学・星 昭二・須藤謙三郎・前野 弘夫・朝沼勇雄 (1961)：ヒメハバ (Trimeresurus okinavensis）の咬傷について。北関東医学，11 (4) : 264-270.

5）木場一夫（1960一a）：奄美群島の爬虫・両棲相 (N). 熊本大学教育学部紀要, $8: 181-191, \mathrm{pl}$. 1.

6）木場一夫（1960-b)：奄美群島のハブの生態, 特に食物・動物学雑誌, $69: 76 \mathrm{p}$.

7）木場一夫（1961）：奄美群島における八ブおよび ヒメハブの食物について，熊本大学教育学部紀 要, 9:220-229, pls. 2 .

8）木場一夫（1962）：奄美群島及びトカラ群島産八
ブ属に関する研究. 119 pp., pls. 39, 日本学術振 興会. 東京.

9）木場一夫（1963）：奄美群島における八ブ及びヒ メハブの食物汇ついて (追記，1). 熊本大学教育 学部紀要, $11: 35-40, \mathrm{pl} .1$.

10）三島章義（1961）：ハブとその被害及び対策。41 pp. 鹿児島県衛生部，鹿児島.

11）三島章義（1965）：奄美のへビ. 大阪自然科学研 究会, Nature Study, 11（2）: 14-19.

12）三島章義（1966）：ハブに関する研究 I ，奄美群 島産八ブの食性について。衛生動物, 17 （1）: $1-17$, pls. 4.

13）化学及血清療法研究所大阪事務所（1056）： マム シの生態と被咬傷患者の実態調査. 10 pp. 化血 研, 大阪.

14）中村健児 -上野俊一（1963）：原色日本両生爬虫 類困鑑・保育社, 東京.

15）高良鉄夫（1953）：琉球の毒へビ。琉球大学校外 普及部, 普及業書, $6: 1-15$, pls. 2 .

16）高良鉄夫（1962）：琉球列島记おける陸棲蛇類の 研究. 琉球大学農家政工学部学術報告, 9 : 1 202, pls. 22 .

17）高良鉄夫（1963）：ハブ(恐るべき毒へビの全貌）。 $193 \mathrm{pp}$. 新光社.沖繩.

18）館野 功・沢井芳男・牧野正顕 (1964)：マムシ 咬傷. 現状, 特にその死因について。日本医事新 報, 2095: 15-17. 